Orbis Tertius, vol. XXVI, nº 34, e219, noviembre 2021 - abril 2022. ISSN 1851-7811

Universidad Nacional de La Plata

Facultad de Humanidades y Ciencias de la Educación

Centro de Estudios de Teoría y Crítica Literaria

\title{
La imaginación del museo. Francisco Xavier Clavigero y la reconfiguración del archivo virreinal
}

\author{
The imagination of the museum. Francisco Xavier Clavigero and the \\ reconfiguration of the viceregal archive
}

Luca Salvi

luca.salvi@univr.it

Università di Verona, Italia

Recepción: 15 Abril 2021

Aprobación: 08 Agosto 2021

Publicación: 01 Noviembre 2021

Cita sugerida: Salvi, L. (2021). La imaginación del museo. Francisco Xavier Clavigero y la reconfiguración del archivo virreinal. Orbis Tertius, 26(34), e219.

https://doi.org/10.24215/18517811e219

\begin{abstract}
Resumen: Este trabajo analiza la naturaleza (parcial y destructora) del archivo novoshispano, sus cruces y tramas, a partir de la obra de Francisco Clavigero, uno de los más señalados archivistas, coleccionistas, erudito de los objetos del mundo prehispánico y novohispano. En un trabajo de reconstrucción e imaginación de ese pasado, Clavigero propone un reordenamiento de materiales, discute la conformación del discurso histórico y da cuenta de la configuración de un archivo criollo.
\end{abstract}

Palabras clave: Museo, Colección, Inventario, Archivo, Virreinato.

\begin{abstract}
This essay analyzes the nature of the "novohispano" archive, its crossroads and textures, focusing in the work of Francisco Clavigero, its collection and its knowledge of the objects and materials of ancient Mexico. By reimagining this past, Clavigero reorients various objects and materials, discusses the very nature of the historical discourse and shows how the "criollo" archive is formed.
\end{abstract}

Keywords: Museum, Collection, Inventary, Archive, Virroyalty.

"La muerte", sostiene Roberto González Echeverría, "es el tropo estructurador del principio de Archivo" (2011, p. 63). Si, parafraseando a Foucault, el archivo se determina como la condición misma del saber y el principio de autorización de los discursos que custodia y permite, reproduce y organiza (Foucault, 2002, p. 219), es imposible, sin embargo, no reconocer en su fisionomía abarcadora y totalizante las huellas de la destrucción. Benjamin, por otro lado, ya había reconocido esta conformación natural del archivo en tanto fundamento de toda cultura, mirando hacia él a través de los ojos del Angelus Novus de Klee: el pasado del archivo, su arché, es un conjunto de escombros y deshechos que lo determina, en su dimensión histórica, como un acontecimiento que emerge solo a partir de un proceso de aniquilamiento (Benjamin, 2008, pp. 44-45), como el resultado de la exclusión y la borradura.

Hacia 1566, el franciscano Fray Diego de Landa había de bosquejar, casi del mismo modo, evocando la expedición de conquista de la región de Yucatán y la campaña de extirpación de la idolatría que avanzó paralela a la operación militar, el espacio germinal del archivo virreinal novohispano: 
Usavan también esta gente de ciertos caracteres o letras con las cuales escrivian en sus libros sus cosas antiguas, y sus sciencias, y con ellas, y figuras, y algunas señales en las figuras entendían sus cosas, y las davan a entender y enseñavan. Hallamosles grande numero de libros destas sus letras, y porque no tenian cosa en que no uviesse supersticion y falsedades del demonio se los quemamos todos, lo cual a maravilla sentian, y les dava pena (Landa, 1864, p. 316).

El fuego, la quema de esos libros escritos con letras imposibles e inequívocamente demoníacas, se vuelve, en la Relación de Diego de Landa, herramienta material de construcción del archivo colonial y evocación simbólica de su naturaleza más profunda. La hoguera de códices es la instantánea del archivo captado en uno de los momentos esenciales de su nacimiento. Los "libros" indígenas que custodiaban la tradición y el saber -sus cosas antiguas, y sus sciencias - y que materializaban en la superficie pintada del papel amate el espacio conceptual de la cultura maya junto con los modos de su transmisibilidad, dejan, como consecuencia de la acción obliteradora de los españoles, el espacio en blanco a partir del cual se irá edificando, luego, el archivo colonial novohispano. En un proceso que acabará por sustituir el amoxcalli por la biblioteca, el códice pictográfico por el libro europeo (Gruzinski, 2013, p. 10), "el primer efecto de la Conquista sobre la memoria indígena fue la destrucción del sistema estatal que recogía y propagaba el pasado por medio de los códices" (Florescano, 1999, p. 232), ${ }^{1}$ determinando así la cultura colonial y los métodos de su reproducibilidad y transmisibilidad sobre la base del rechazo y la exclusión de las formas del saber indígena.

\section{2.}

A finales del siglo XVIII, el jesuita veracruzano Francisco Xavier Clavigero insiste en la naturaleza parcial y destructora del archivo novohispano en las páginas de una breve carta que envía, el 13 de junio de 1780, desde su exilio en Bolonia, a los académicos de la Real y Pontificia Universidad de México. ${ }^{2}$ El texto, que acompaña y presenta la primera edición italiana de la Historia antigua de México, se detiene en una reflexión sobre las relaciones que la actividad de reconstrucción historiográfica entretiene con los vacíos del archivo. ${ }^{3}$

La Historia que se acaba de publicar, confiesa Clavigero, resulta, en este sentido, una obra muy "defectuosa" (2009, p. XVII), porque es el resultado de una actividad intelectual que se determina y desarrolla exclusivamente a partir de la falta y de la lejanía. "Más bien que una historia" -se lee en la carta- "es un ensayo, una tentativa, un esfuerzo atrevido", realizado "explorando un camino que, por nuestra desgracia, se ha hecho dificultosísimo" (Clavijero, 2009, p. XVII). En Clavigero esta dificultad surge, en primer lugar, de las circunstancias históricas del exilio. Es el "miserable estado" (Clavijero, 2009, p. XVII) del destierro el que impone al historiador el alejamiento y la inaccesibilidad de las fuentes, determinando el acervo documental en tanto archivo ausente o, en el mejor de los casos, incompleto e incierto. ${ }^{4}$ Sin embargo, la reflexión acerca de la contingencia biográfica de la escritura conduce, en el discurso clavigeriano, hacia una profunda reconsideración del archivo virreinal novohispano, volviendo a poner en tela de juicio su conformación presente sobre la base de su trayectoria histórica. La imposibilidad de acceso al archivo causada por el exilio se vuelve síntoma y paradigma de una condición más profunda que ha ido caracterizando el conjunto del itinerario vital de la cultura novohispana:

Pero dejando por ahora las alabanzas que os son debidas, porque acaso parecerán adulaciones a los que ignoran vuestro relevante mérito, quiero quejarme amistosamente de la indolencia o descuido de nuestros mayores con respecto a la historia de nuestra patria. Cierto es que hubo hombres dignísimos que se fatigaron en ilustrar la antigüedad mexicana y nos dejaron de ella preciosos escritos. También es cierto que antes hubo en esa Universidad un profesor de antigüedades, encargado de explicar los caracteres y figuras de las pinturas mexicanas, por ser tan importantes para decidir en los tribunales los pleitos sobre la propiedad de las tierras o la nobleza de algunas familias indias, y esto es puntualmente lo que me causa pena. ¿Por qué no se conserva aquel profesor tan necesario? ¿Por qué se han dejado perder aquellos escritos tan preciosos y especialmente los del doctísimo Sigüenza? Por faltar el profesor de antigüedades no hay actualmente quien entienda las pinturas mexicanas, y por la pérdida de los escritos, la historia mexicana se ha hecho dificilísima, por no decir imposible (2009, p. XVIII). 
Lo indígena, sintetizado en la materialidad de aquellos caracteres pintados que Diego de Landa veía manchados por la falsedad y la superstición, es, para Clavigero, a la vez fundamental y exterior. Fundamental, porque sin esa clase de documentos el funcionamiento sociopolítico mismo del virreinato se volvería imposible, faltando los elementos mínimos capaces de proporcionar los datos para la edificación de un relato abarcador de la realidad mexicana; exterior, porque la evolución de la cultura colonial, a partir de la indolencia y descuido de los españoles - nuestros mayores - hasta la abolición de la cátedra de antigüedades antes ocupada por Carlos de Sigüenza y Góngora, había ido determinando una exclusión sustancial de las fuentes indígenas (y un ocultamiento de los textos que se habían dedicado a estudiarlas y explicarlas) dentro del patrimonio de saberes de la cultura virreinal. En consecuencia, el vacío que aquí Clavigero presenta y condena reconfigura la labor historiográfica como tarea imposible.

Pero es en el libro sexto de la Historia antigua donde el problema del archivo mutilado adquiere una forma específica. No se trata aquí, como en Diego de Landa, de documentar la destrucción de los vestigios materiales de la tradición idolátrica de los indios de Yucatán, sino de presentar, en el marco de una cuidadosa reconstrucción arqueológica de la arquitectura religiosa azteca precortesiana, una descripción del Templo Mayor de Tenochtitlán, dedicado al dios Huitzilopochtli:

Este es el templo que tanto celebraron los españoles después de haberlo arruinado. Apreciaríamos que hubiese sido tanta su exactitud en las medidas que nos dejaron, cuanto fue su celo en demoler aquel soberbio monumento de la superstición; pero es tan grande la variedad con que escriben que, después de haber trabajado mucho en combinar sus descripciones, no he podido enterarme de sus medidas, ni hubiera jamás formado idea de la forma de su arquitectura si no hubiera tenido la fortuna de ver la imagen que nos presenta a los ojos el Conquistador Anónimo, cuya copia damos al público en la lámina, aunque en las medidas seguimos más lo que expresa en su relación que lo que representa la imagen. Diré pues, lo que he podido averiguar por la prolija combinación de las descripciones de cuatro testigos oculares, omitiendo lo que dudo por la confusa relación de los autores (Clavijero, 2009, pp. 224-225).

Es evidente que la lámina (figura 1) es el resultado de un proceso de investigación y documentación finalizado a la restitución fiel de la imagen del templo, funcionando además como soporte visual de la descripción discursiva que la acompaña. La relación que articula imagen y texto, aquí, es la misma que organiza, en sentido moderno, la historiografía como relato construido a partir de documentos y pruebas. Sin embargo, el texto, en este punto, establece una relación conflictiva con la imagen, cuestionando su valor y su objetividad. No importa tanto aquí que el testigo más confiable que tiene Clavigero sea el discutido Conquistador Anónimo, que probablemente nunca pisó el suelo novohispano y construyó su imagen del Templo Mayor a partir de fuentes ajenas. ${ }^{5} \mathrm{Ni}$ importa mucho que los otros tres testigos oculares a los que se refiere Clavigero -a saber, Hernán Cortés, Bernal Díaz del Castillo y Sahagún- hayan entregado a sus lectores unas descripciones del templo hechas de medidas y formas incongruentes. Lo fundamental es, en cambio, que la imagen señala en este caso el espacio de un vacío documental que solo en parte es posible completar. 
Figura 1. Il Tempio maggior di Messico (Clavigero, 1780-1781, p. 27).

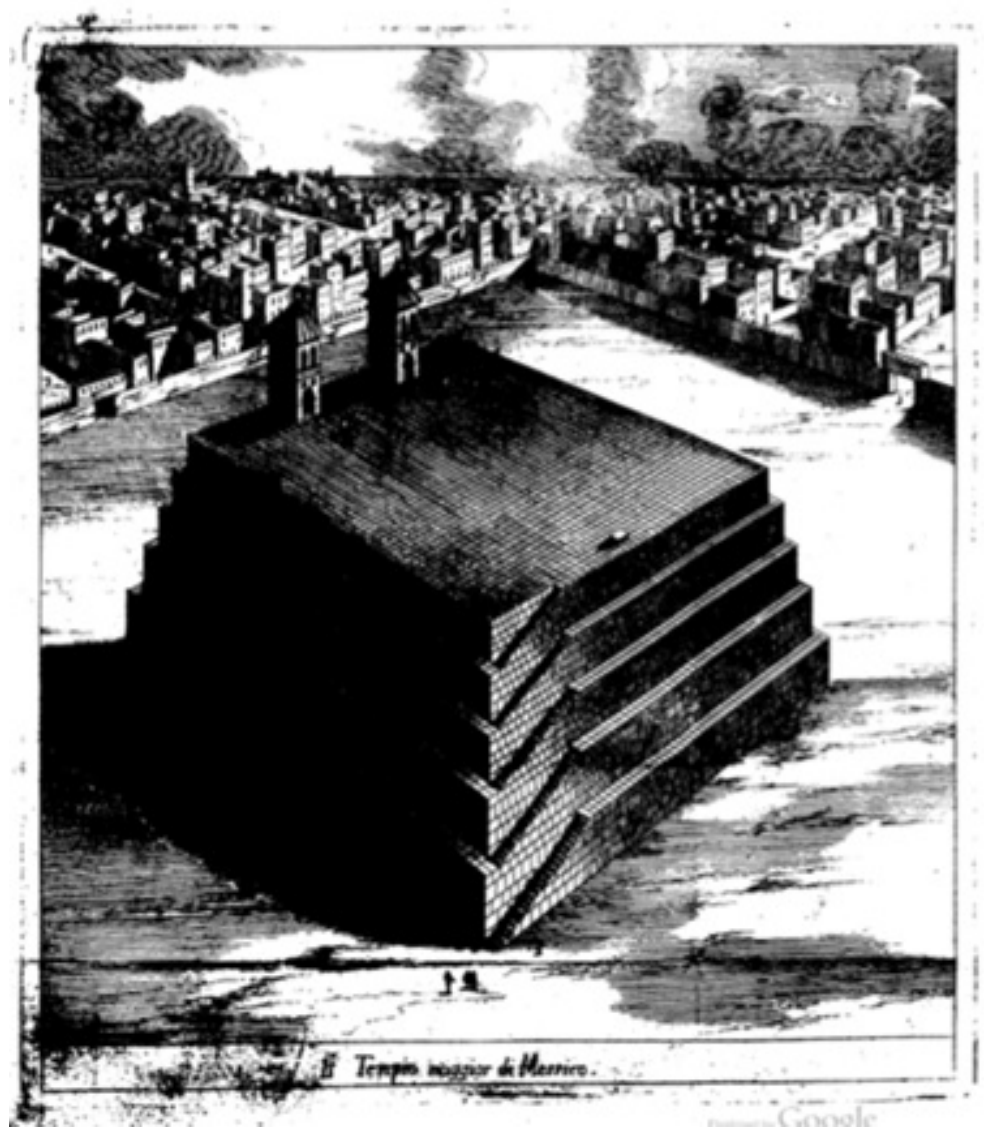

El discurso enfrenta en este punto la inexistencia de su objeto y denuncia explícitamente la desconfianza hacia sus fuentes, bosquejando los contornos de un hueco en el archivo que compromete el respeto de aquellas "santas leyes de la historia" evocadas por Clavigero en su prólogo (2009, p. XXII). De este modo el relato se redefine como discurso inestable y conjetural. Lo relevante, sin embargo, es que esta imposibilidad historiográfica constituye el fundamento mismo de la cultura novohispana y demuestra la naturaleza de sus comienzos: el celo en demoler es, en Clavigero, otra paradójica figura de construcción del archivo.

\section{3.}

Sin embargo, la formulación clavigeriana de la historia imposible no se entiende si no se la sitúa en el cruce de los cambios a los que se somete la perspectiva criolla a lo largo del siglo XVIII. ${ }^{6}$ Hay que concordar con Solodkov y Vitulli, cuando describen lo criollo como un "tropo en constante transformación” (2009, p. 13) capaz de determinar y modular la emergencia de sentidos políticos, lingüísticos y filosóficos siempre diferentes, modificando así, una y otra vez, el archivo americano. Y la fisionomía mutilada del archivo mexicano hacia la que mira incesantemente Clavigero no es, desde esta perspectiva, otra cosa sino el resultado de un cambio sustancial que redefine el mismo lugar enunciativo desde el cual esta hipótesis es formulada.

Claro es que en Clavigero el punto de vista se modela a partir del ambiente cultural de la época, empujando hacia una redefinición de lo americano en sentido antagónico con respecto a las imágenes del Nuevo Mundo que, por ese entonces, animaban el debate filosófico de los círculos ilustrados europeos y que, en el caso de la Historia antigua de México, causará la hibridación del discurso historiográfico con el ensayo crítico y el panfleto de denuncia. ${ }^{7}$ 
En todo caso, la vertiente polémica solo es una de las caras de la operación clavigeriana. La tarea de restituir la verdad sobre América, desmintiendo las falsedades de los philosophes europeos, se inserta más bien en un proceso complejo de redefinición de lo americano en el cual el jesuita veracruzano se involucra de manera del todo voluntaria y consciente. Se trata menos, en Clavigero, de desenterrar y reivindicar una imagen ya existente de la patria, que de crear México como entidad histórica y cultural completamente nueva (Cuevas, 2009, pp. XI-XII).

El antecedente fundamental, aquí, es evidentemente el de la Bibliotheca mexicana que Eguiara y Eguren publicó en latín en 1755 para desmentir las acusaciones del canónigo alicantino Manuel Martí sobre el retraso (más bien la ausencia, en las palabras del español) de la cultura novohispana. En el segundo de los veinte Anteloquia que acompañan la Bibliotheca, siguiendo el ímpetu de la polémica y la reivindicación -con el fin de probar "cuán grande es la ignorancia del deán alicantino en punto a antigüedades mexicanas" (1996, p. 60)-, Eguiara y Euguren presenta su personal visión del archivo novohispano:

\begin{abstract}
Los mexicanos cultivaron además la poesía, la retórica, la oratoria, la aritmética, la astronomía y otras disciplinas, de las que nos quedan los monumentos insignes y testimonios dignos de entero crédito, que aduciremos en nuestro Prólogo IV. La aguda inteligencia que caracterizaba a sus hombres principales, insignes por su calidad sacerdotal y cargos públicos, danla a entender las figuras e imágenes a manera de letras y de diversos colores, sumamente apropiadas a la significación de los objetos, de que se valían, grabándolas en piedras y maderas o dibujándolas en grueso papel, semejante al que entre nosotros se usa para envoltorios $y$, a las veces, en pieles finamente trabajadas o en flexibles pergaminos. Por este procedimiento solían legar a la posteridad cuanto consideraban digno de recordarse y juntamente el día, mes y año de sus orígenes y de su inmigración en esta nuestra América. Entre los cinco libros más importantes de la nación se contaban las "Ruedas" pintadas con arte primoroso (p. 63).
\end{abstract}

La imaginación traductora de Eguiara y Eguren transforma aquí el códice en libro, mientras que reconoce en los pictogramas un esbozo de alfabeto colorado hecho de figuras sumamente apropiadas a la significación y, por lo tanto, al desarrollo de las artes y las ciencias. Es esta una tentativa de adecuación de la cultura indígena a los modelos occidentales de evolución de las civilizaciones que transforma el archivo virreinal, reconfigurándolo en un sentido incluyente y conduciendo hacia una versión transculturada de la tradición mexicana y de su acervo documental. Se rechaza, en estas líneas, el modelo destructor de la tradición colonial, al que habrá de volver más adelante Clavigero, para recuperar, más bien, ese "universalismo jesuita" que para Octavio Paz había marcado la obra de Sigüenza y Góngora (Paz, 1997, pp. 209-210), ' y que daría lugar, en el Teatro de virtudes políticas (1680), a una de las más poderosas imágenes de recomposición del archivo. ${ }^{9}$ Frente a las calumnias europeas, Eguiara y Eguren elabora una forma de la identidad -nuestra patria y nuestro pueblo (1996, p. 58)- que se obtiene mediante la homologación de saberes y la unión de tradiciones, anticipando así un proceso de reivindicación autonomista que se exacerbará en las últimas tres décadas del siglo y que llevará a la crisis del sistema político del virreinato. ${ }^{10}$

El problema de la imposibilidad de la historia se vuelve así más descifrable: la historia mexicana es, para Clavigero, como en los Anteloquia de Eguiara y Eguren, aquella "de las dos 'naciones' que sucesivamente dominaron e ilustraron el sol patrio: la 'nación' azteca primero y la 'nación' criolla más tarde” (Lafaye, 2002, p. 518). ${ }^{11}$ Sin embargo, la tarea de escribir la historia de la "sola e individua nación” (Clavijero, 2009, p. 300) mexicana, en la que participarían, a la vez, el pasado indígena y la tradición cultural española, por supuesto en el marco de la trayectoria vital de la clase criolla, se enfrenta una y otra vez con el vacío documental que reconfigura a lo indígena, su sistema de conocimientos y de transmisión de saberes, en los términos de una exterioridad del archivo.

4.

A partir de esta perspectiva, ¿cómo escribir la historia de México si el archivo cultural virreinal ha ido determinando, en el curso de la historia colonial, la negación misma de esta posibilidad? ¿Cómo enmendar la 
destrucción y reintegrar el archivo, recuperando y reactivando, desde la perspectiva dieciochesca de la mirada criolla, aquellos elementos que habían sido destruidos, o, en el mejor de los casos, ocultados y marginados? ${ }^{12}$ En Clavigero, todas estas preguntas adquieren una dimensión novedosa que refleja directamente el contexto cultural dentro el cual el jesuita veracruzano está moviéndose.

En otro pasaje de la dedicatoria dirigida a la Universidad de México, Clavigero intenta responder a estos interrogantes, al avanzar la hipótesis de una remodelación del archivo novohispano, tanto en sentido material como epistemológico: Yo espero que vosotros, que sois en ese reino los custodios de las ciencias, trataréis de conservar los restos de las antigüedades
de nuestra patria, formando en el magnífico edificio de la Universidad, un museo no menos útil que curioso, en donde se
recojan las estatuas antiguas que se conservan o que se vayan descubriendo en las excavaciones, las armas, las obras de mosaico
y otros objetos semejantes; las pinturas mexicanas esparcidas por varias partes, y, sobre todo, los manuscritos, así los de los
misioneros y otros antiguos españoles, como los de los mismos indios, que se hallan en las librerías de algunos monasterios,
de donde se podrán sacar copias antes de que los consuma la polilla o se pierdan por alguna otra desgracia. Lo que hace pocos
años hizo un curioso y erudito extranjero (el caballero Boturini) nos indica lo que podrían hacer nuestros compatriotas, si
a la diligencia y cuerda industria unieran aquella prudencia que se necesita para sacar esta clase de documentos de manos de
los indios $(2009$, p. XVIII).

El museo imaginado que Clavigero bosqueja en estas breves líneas -y que Florescano (1993, p. 162) reconoce como el primer proyecto de museo, en sentido moderno, en la historia mexicana- es una figura de archivo. Y el museo-archivo es, a la vez, de acuerdo con Foucault, heterotopía y heterocronía (Foucault, 2001, p. 1578). Es la imagen conceptual, todavía borrosa e imprecisa, de un acervo material heterogéneo, al mismo tiempo indígena y español, de una forma de la cultura transversal y totalizadora capaz de recoger en sí las dos caras complementarias de la sola e individua nación que Clavigero postulará más adelante en su obra. Una novedad epistemológica, sin embargo, la del museo, que se inscribe genealógicamente en una larga tradición de coleccionismo novohispano. Un repertorio, el que el jesuita criollo ve, en el futuro, custodiado entre las paredes de la Universidad, que tiene un antecedente fundamental en el arquetípico acervo de códices que recogiera el cronista texcocano Fernando de Alva Cortés Ixtlilxóchitl en la primera mitad del siglo XVII y que pasará luego a manos de Carlos de Sigüenza y Góngora, hasta integrar la imponente colección (alrededor de 350 piezas) de aquel Museo Indiano que el anticuario italiano Lorenzo Boturini Benaduci armará entre 1736 y 1742, y que formará, luego, la base para la redacción de su Idea de una nueva historia de la América Septentrional, publicada en $1746 .^{13}$

El coleccionismo novohispano le proporciona entonces a Clavigero el ámbito de una tradición historiográfica de referencia. Un modelo, además, que reproduce la fisionomía de una tradición íntimamente heterogénea y caracterizada por una estratificación plural de puntos de vista, que van desde la perspectiva de la nobleza indígena de Ixtlilxóchitl, hasta el criollismo de Sigüenza y Góngora o la historiografía devota del italiano Boturini. Sin embargo, el museo imaginado debe leerse, sobre todo, en relación con su tiempo y, particularmente, con el nacimiento y el auge de la institución del museo público en los centros culturales europeos. Un acontecimiento, este, que, en el centro imperial español había dado inicio, en aquellos años, a un proceso masivo de musealización institucional de las cosas americanas, hasta entonces esparcidas en una fragmentada galaxia de colecciones privadas que habían ido incorporando ya esta clase de objetos a partir del siglo XVI. ${ }^{14}$ Recontextualizado a partir de su reinterpretación por parte de la epistemología ilustrada, el objeto americano ingresaba a las salas del museo europeo para ser expuesto como prueba, "en tanto que manufactura representativa de los pueblos indígenas en el nivel cultural en que éste se hallase” (Cabello Carro, 2001, p. 306). ${ }^{15}$

Empero, es prácticamente imposible que Clavigero no haya notado la incongruencia de estos dos archivos, del europeo y del virreinal, en los que los objetos indígenas acabarían desempeñando un rol muy relevante. Por un lado, bajo el control del pensamiento ilustrado occidental y sobre la base de esta nueva función etnográfica, los objetos se erigían al rango de pruebas y documentos, trascendiendo su colocación tradicional en el ámbito 
de las meras curiosidades. Pruebas y documentos que, no obstante, demostraban científicamente, a los ojos de los philosophes europeos, la inferioridad americana, su inmadurez -en sentido kantiano- y su lejanía histórica respecto al modelo de la civilización europea. Por otro lado, como se ha visto en el caso de la imposible reconstrucción del Templo Mayor intentada por Clavigero, el objeto seguía exponiendo, a la mirada crítica del historiador criollo, los límites de un archivo fragmentado y no reconstruible, marcando el espacio de una imposibilidad historiográfica que resonaba en los bordes movedizos de una tradición borrosa, perfilándolas formas inciertas de una identidad inestable.

\section{5.}

La historiografía clavigeriana, al imaginar aquel museo no menos útil que curioso con la intención de remediar la mutilación del acervo documental mexicano, se convierte, en algunas de sus secciones fundamentales, en un relato compuesto de objetos. El museo, en efecto, es un modo de la historia. Una forma híbrida, sin embargo, en la que relato verbal y materialidad confluyen, entrecruzándose, en la edificación del discurso. Pomian, describiendo esta peculiar relación entre palabra y objeto, destaca que:

...en la variante museística de la narración histórica, el texto no basta, pues, por sí solo, no es autónomo en relación al objeto del que ofrece un comentario. La lectura acompaña en este caso la mirada. La informa y la orienta, pero no la sustituye (2007, p. 26).

Es así que, a lo largo de sus primeros siete libros dedicados a la descripción de la historia, la cultura y la vida cotidiana de los aztecas antes de la llegada del ejército cortesiano -otro tema, este, del que se encargarán los últimos tres libros de la obra-, el discurso del historiador se mezcla con la exposición visual de algunos de los elementos característicos de la civilización mexica y de su entorno natural. Una serie de veinte láminas, que acompañan la primera edición italiana del texto, concretizan, frente a la mirada de los lectores, instantáneas de la realidad, natural y cultural, del Anáhuac prehispánico, y esbozan, en su interrupción del relato verbal, algunas de las salas del museo imaginado. ${ }^{16}$

Pero, ¿cuál es la función que desempeñan estas imágenes y qué relación tienen con el discurso que acompañan? En su nivel más superficial, la imagen es una herramienta de la explicación. El objeto expuesto completa el relato verbal y la imagen sirve así "no menos por hermosear (...) que por facilitar la inteligencia de algunas cosas descritas" (Clavijero, 2009, p. XXIII). Las cosas -flores y animales, edificios, armas, instrumentos musicales y juegos, entre otros-, recuperadas y expuestas, se cargan aquí de una función que es a la vez didáctica y científica y que Clavigero hereda del ejemplo ilustrado del museo enciclopédico europeo, ${ }^{17}$ pero que condensa con la vocación filosófica y pedagógica que rige la actividad intelectual de la Compañía de Jesús en la base de los preceptos de la Ratio Studiorum. ${ }^{18}$

Sin embargo, el aparato expositivo de la Historia antigua, lejos de constituirse en una taxonomía exhaustiva de la realidad mexicana, y contraviniendo por lo tanto a sus orígenes enciclopédicos, da cuenta de un cuidadoso proceso de selección. Es el caso de la primera lámina (figura 2) donde se retratan nueve especies de flores y frutos de Anáhuac y que interactúa con una porción textual que cubre los capítulos de 8 a 11 del "Libro primero", dedicado precisamente a la descripción de la naturaleza del Reino de México. Ya a partir del párrafo introductorio de esta sección dedicada a la botánica mesoamericana, la operación de selección de los materiales que se van a exponer resulta determinante, justamente porque se constata la hiperbólica variedad de la flora americana:

Pero siendo tan abundante y rico el reino mineral de México, es incomparablemente más copioso y vario el reino vegetable. El célebre Dr. Hernández, el Plinio de la Nueva España, describe en su Historia natural mil y doscientas plantas nativas de aquella tierra, y es cierto que apenas describe una parte de los innumerables vegetales que ha producido allí la naturaleza; pues la fitografía apenas comprende otras plantas que las medicinales, de las cuales daremos alguna razón cuando trataremos de la medicina de los mexicanos (2009, p. 14). 
Figura 2. Piante messicane (Clavigero, 1780-1781, p. 57).

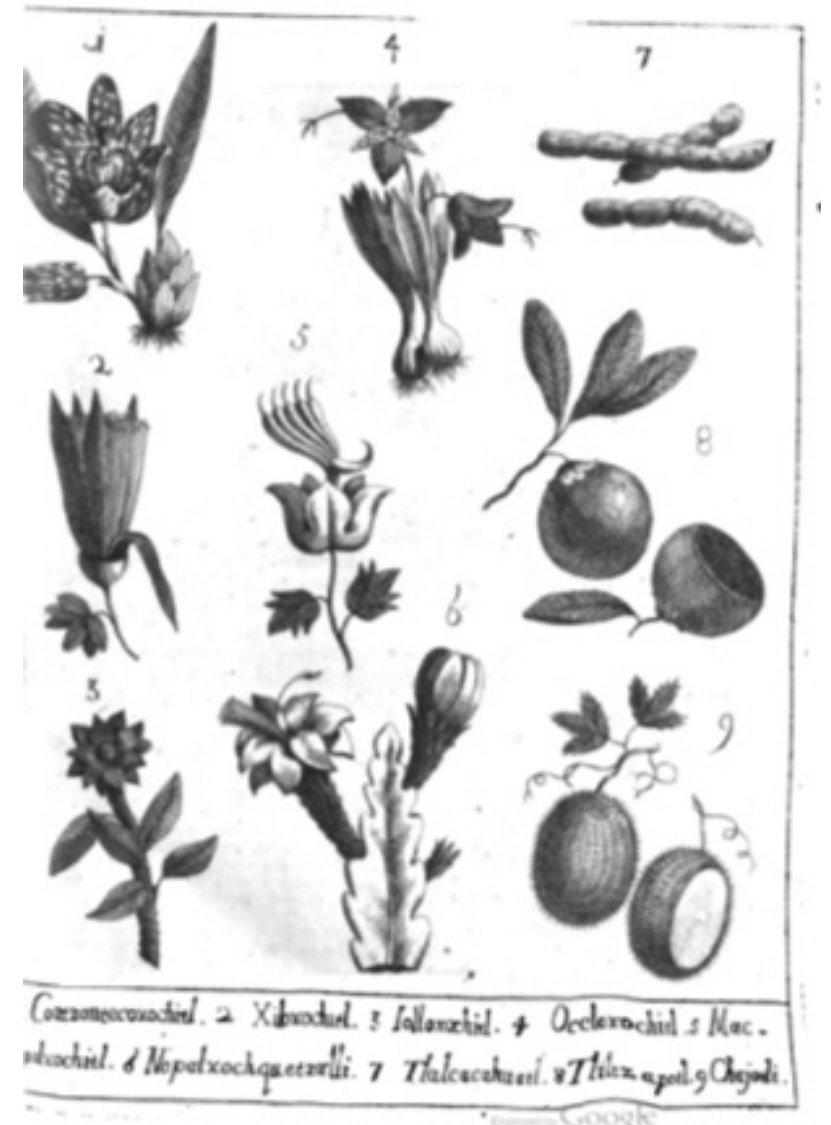

El archivo enciclopédico que Clavigero tiene a disposición -y que es aquí el de la Historia natural de Francisco Hernández, escrita a finales del siglo XVI- se acota y reduce, para dar forma a una sintética antología vegetal. Ahora bien, ¿qué es lo que se conserva y selecciona? De la infinita variedad de flores que presenta Hernández, el museo-historia clavigeriano conservará solo aquellos ejemplares dignos "de particular mención por la maravillosa belleza de sus colores o por su singular fragancia o por su figura extraordinaria" y que, precisamente por estas calidades, "hermoseaban las campiñas o adornaban los jardines de los antiguos mexicanos" (p. 15) y hasta se encontraban muy difundidos como decoración religiosa en los templos de la Nueva España (p. 16).

El énfasis se pone en la inscripción humana del objeto vegetal, destacando su función cultural en el ámbito de la historia mexica. La flor se convierte así en una entidad que es simultáneamente material y simbólica, objeto y cultura, de la cual se describen las calidades físicas (el olor, los colores, las formas), solo para ensalzar el contexto humano de su uso (los jardines, los templos). Las flores, de las cuales se proporciona directamente a los lectores el nombre en náhuatl, con apenas un esbozo de traducción literal, se convierten en el curso del relato clavigeriano en signos culturales. Es el caso, por ejemplo, del coatzontecoxóchitl, "una especie de lirio de una belleza imponderable" (p. 15) que el historiador selecciona para su lámina pero que describe únicamente de manera sumaria -"sus hojas son rojas pero salpicadas de puntos blancos y amarillos. Su nombre expresa su semejanza con la cabeza de una culebra” (p. 15)-, destacando, sin embargo, otra vez, su función humana: “era ésta una de las flores que tenía más estimación entre los mexicanos" (p. 15). ${ }^{19}$

La culturalización de las cosas, sin embargo, no es un fin en sí mismo. Responde, por el contrario, a una necesidad primaria que informa todo el proyecto historiográfico y filosófico de Clavigero, redefiniendo el discurso de la historia como un ejercicio de comparativismo cultural. Lo mismo acontece en relación con otros aspectos de la vida cotidiana y material de los aztecas. De los juegos (figura 3) -desde aquellos que sirven 
a "la utilidad del Estado" (p. 345) como las carreras, en las que los mexicas "además de la inocente diversión que se daba al pueblo, se agilitaban y ejercitaban para las fatigas de la guerra” (p. 345), hasta los frívolos y menos útiles como el de voladores, de la pelota y otras formas de danzas- Clavigero destaca precisamente su valor universal. "Como las demás naciones" (p. 345) del mundo, los aztecas jugaban y danzaban, y del mismo modo percibían el mundo a través del filtro de un sentido de la belleza que permitía la conversión de la naturaleza en adorno u objeto religioso. Al ser involucrado en el relato museístico, el objeto se carga de una nueva función semántica: además de coadyuvar a la comprensión del realtoescrito, "sus propiedades visibles se convierten en signos" (Pomian, 2007, p. 139), determinándolo complementariamente en tanto expósito y semióforo (pp. 138-139).

Figura 3. Las dos láminas que Clavigero dedica a los juegosmexicanos (Clavigero, 1780-1781, pp. 183 y 186).
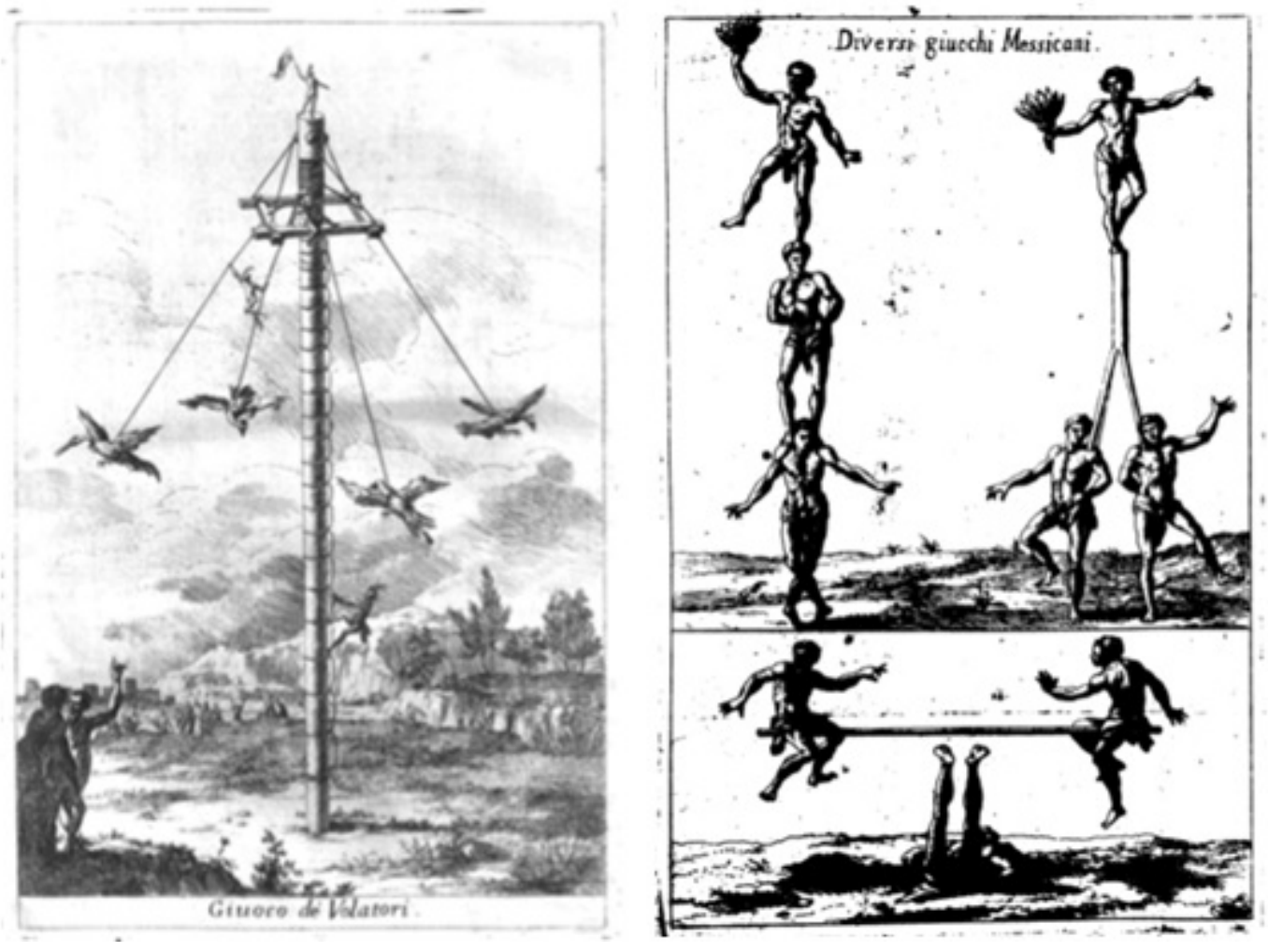

Pero el caso más consistente de resignificación que sufren las cosas a la hora de integrar el relato del museo y que mejor ilustra el tratamiento que Clavigero reserva a los objetos expuestos en las páginas de su Historia antigua sea el de los sacrificios humanos, cuyas imágenes, dedicadas específicamente al sacrificio ordinario y al gladiatorio, ocupan dos láminas del libro sexto (figura 4). También aquí, lo que se destaca -a pesar de "tanta abominación y crueldad", que el autor ahorraría con placer a sus lectores, si no fuera por las obligaciones que le impone el trabajo del historiador (Clavijero, 2009, p. 239)- es la inscripción universal de las prácticas religiosas, ya que "no ha habido casi nación alguna en el mundo que no haya practicado los mismos sacrificios" (p. 239). La mirada del historiador, otra vez, selecciona y ordena, para proporcionar a los lectores-espectadores un relato que pueda definir la esencia misma de la cultura mexica como elemento integrante de la historia general de la humanidad. 
Figura 4. Las dosláminasque Clavigero dedica a los sacrificios humanos (Clavigero, 1780-1781, pp. 47 y 49).
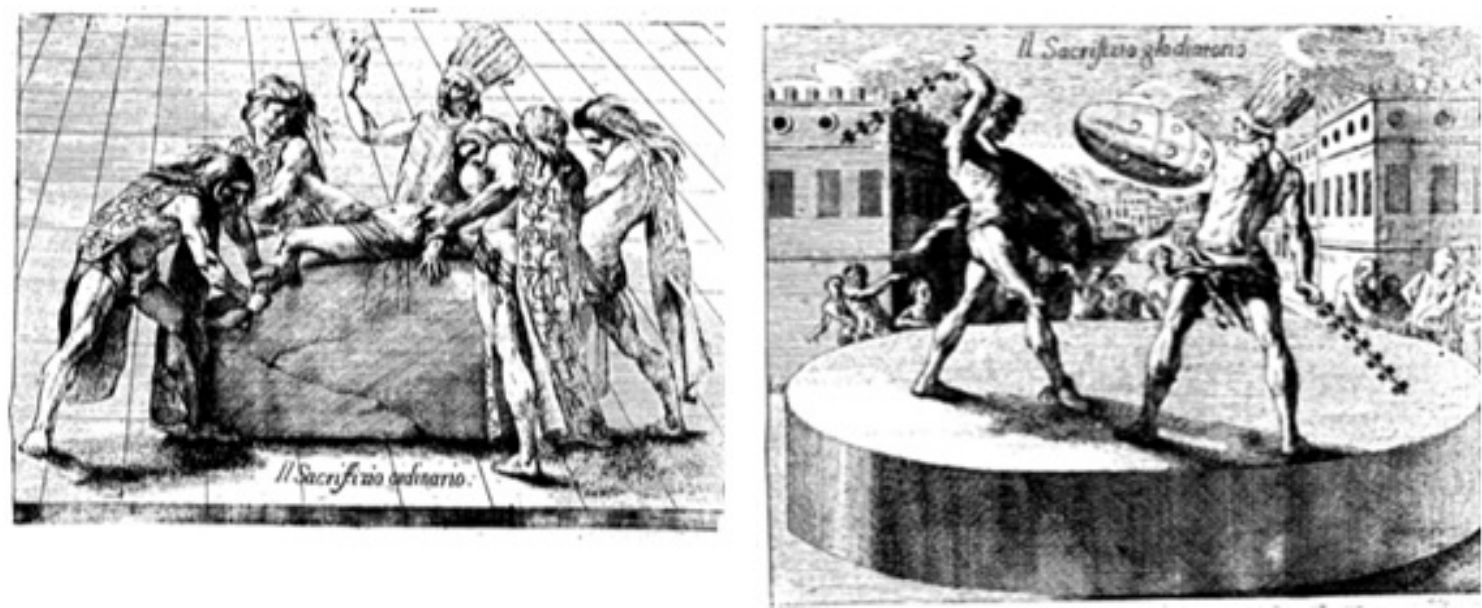

Además, en una relectura histórica que vuelve a modelar el sentido mismo de estos acontecimientos y prácticas culturales, el sacrifico humano se convierte en una muestra de la orientación del continuum temporal en sentido evolutivo y teleológico, al marcar el tránsito que va de la carencia de religión a un sistema confesional que, si bien imperfecto y hasta inhumano desde el punto de vista del religioso, representa un avance sustancial y necesario en la historia de la civilización de Anáhuac: ${ }^{20}$

No sabemos qué especie de sacrificio hacían los antiguos toltecas. Los chichimecas no lo usaron por mucho tiempo, no teniendo al principio ni ídolos, ni templos, ni sacerdotes; después que comenzaron a usar de varios ejercicios de religión, no ofrecían al Sol y a la Luna sino yerbas, flores, frutas y copal. No dieron aquellas naciones en la inhumanidad de sacrificar víctimas humanas hasta que los mexicanos con su ejemplo les hicieron deponer el horror natural (2009, p. 239).

El indígena salvaje, que el sistema imperial había intentado excluir con todas sus fuerzas de la realidad virreinal, pasa a ocupar en Clavigero el espacio cultural e histórico de una recién creada clasicidad mexicana. ${ }^{21}$ Las salas del museo imaginado, edificado in nuce en el espacio ordenado de las láminas que acompañan la Historia antigua, seleccionan y exponen objetos solo para reordenarlos y reconstituirlos semánticamente en el marco de un proyecto de reinterpretación historiográfica que, una y otra vez, vuelve a presentar el problema de la recomposición de la tradición mexicana, a través de la inscripción de la civilización mexica en el ámbito de la historia universal.

Imaginado y escrito, el museo reconfigura, de este modo, la historiografía como inventario. Un inventario particular, sin embargo, claramente no neutral, que como sostiene Umberto Eco (2016, p. 131) adquiere una función netamente ordenadora: el museo y sus objetos, en el marco de una colección que integra y vehicula el punto de vista de su curador, permiten finalmente la posibilidad de dar una forma a aquello donde reinaban exclusivamente el desorden y la dispersión. Una forma y un orden que en la imaginación museística clavigeriana trazan al fin y al cabo el aspecto sintético del archivo recompuesto.

\section{6.}

En el museo existe siempre, desde esta perspectiva, un centro de la significación que presupone determinados parámetros de legibilidad y que organiza el horizonte de los sentidos que lo recorren. En este aspecto, el museo se acerca a la estructura del laberinto; como la aparentemente ilógica construcción de Cnosos, que encuentra su sentido último solo en la esencia del centro alrededor del cual se construye, el museo necesita de un núcleo semántico capaz de sostener con su sola presencia la arquitectura del relato, cohesionando la orquestación de 
espacios y las relaciones de los sentidos divergentes que lo integran. Néstor García Canclini lo nota en el caso del Museo Nacional de Antropología de la Ciudad de México, institución que deriva directamente, del museo imaginado por Clavigero. ${ }^{22}$ El Museo Nacional de Antropología, su potencia significante que reconstruye la historia prehispánica con fines de exaltación nacionalista, no se realiza sino en la articulación simbólica que propone el centro, arquitectónico y narrativo, del edificio, ocupado por la Sala mexica (García Canclini, 2013, pp. 170-173). Es ahí donde se redispone la historia en una imagen temporal lineal y ordenada, para confluir finalmente a la síntesis de la mexicanidad. Entre las paredes que custodian la Piedra del Sol, todos los objetos llamados a actuar en la narración del museo cobran finalmente su sentido en cuanto participantes de un relato de síntesis.

El museo clavigeriano no hace excepción. La consistente cantidad de materiales que moviliza para la edificación de su renovado archivo mexicano -un archivo heterogéneo, como vimos, donde lo indígena participa junto y al lado de lo español-impone la necesidad de un principio de organización capaz de sostener el peso del relato. El asunto de la justificación y autorización de los documentos sobre los cuales se edifica el discurso y construye la idea de museo se hace en este punto impelente.

En una sección preliminar de la obra -la "Noticia de los escritores de la historia antigua de México" (Clavijero, 2009, pp. XXV-XXXVII)- Clavigero expone sus fuentes, organizándolas cronológica y tipológicamente. En el vértigo de la superposición, la posición imperial de las Cartas de Hernán Cortés se alterna con las obras de los religiosos Sahagún, Torquemada o Betancourt, entre muchos otros, para completarse, sin embargo, solo en el espacio de la perspectiva indígena de los varios Ixtlilxóchitl, Chimalpáin y Muñoz Camargo. La biblioteca clavigeriana adquiere de este modo la forma del archivo que quisiera recomponer, en su variedad y transversalidad cultural. Sin embargo, el inventario que se acaba de presentar no se completa sino en aquella sección de su biblioteca que Clavigero dedica a las "Pinturas" mexicanas, destacando "las que se salvaron del incendio de los primeros misioneros" y "las hechas después por los indios historiadores del siglo XVI” (p. XXXV).

Lo que hace aquí Clavigero es precisamente fundar un corpus diferente para la historia mexicana. Si como sostiene Montaldo "en el corpus se suponen valores estéticos y morales, prestigio y saber, se incluyen textos que es necesario leer y se excluyen los que no se pueden leer" (2001, p. 74), el proceso de selección que subyace en la construcción de la biblioteca clavigeriana redefine el concepto mismo de auctoritas dentro del contexto de la práctica historiográfica novohispana. La tradición del códice pictográfico se recupera de la exclusión epistemológica que nace al sustituirla con el modelo europeo del libro. Ahora se la homologa, a través de su misma inclusión en el acervo de la biblioteca mexicana de Clavigero, con la tradición historiográfica europea. Pero, a partir de estos presupuestos, ¿cómo se hace posible la autorización del signo indígena, su nueva inserción en el espacio de un corpus, el novohispano, que había ido determinando, en los últimos dos siglos y no obstante algunas ilustres excepciones, la exclusión de esas formas del saber? Para volver a la cuestión de arranque, es necesario preguntarse, ahora, sobre cuál es el centro del corpus (y del museo) mexicano de Clavigero y de qué modo este logra organizar y cohesionar visiones de la historia y modos del saber de tradiciones tan diferentes como la prehispánica y la europea.

Discutiendo en el libro séptimo sobre el sistema de leyes inaugurado por el tlatoani texcocano Nezahualcóyotl, celebrado por Torquemada y Alva Ixtlilxóchitl y figura relevante en el programa historiográfico clavigeriano, la Historia antigua destaca el valor que la fijación del pasado y los modos de su transmisión tenían entre los antiguos mexicanos: "el mismo Nezahualcóyotl”, atesta Clavigero, "estableció pena de muerte contra los historiadores que publicasen en sus pinturas alguna falsedad" (Clavijero, 2009, p. 312). El discurso de la Historia antigua, efectivamente, convierte al tlatoani, mediante un proceso que es a la vez retórico y simbólico, en una imagen precursora de ese archivo recompuesto e integral que Clavigero imagina ya en las postrimerías de la historia virreinal. El noble indígena, de esta suerte traducido al topos occidental del "rey sabio" (Payàs Puigarnau, 2010, p. 265), funciona aquí como punto de articulación que organiza la historia mexicana como una sucesión entre lo indígena y lo europeo. Si Nezahualcóyotl es a la vez 
rey poeta y científico, el acento que Clavigero pone sobre las leyes que regulaban el trabajo de los historiadores mexicas es para el autor una estrategia de reconfiguración radical de las fuentes.

Bajo el sello del control sobre la verdad que impusiera el tlatoani texcocano, las "figuras oscuras" (Clavijero, 2009, p. 395) de los códices pueden de este modo integrarse en última instancia al museo (figura 5), para cargarse ahora de un principio de legibilidad y legitimidad que autoriza su inclusión en el corpus de la historia. Es este el punto fundamental de un proceso que, en Clavigero, remodela lo demoníaco y falso de los que hablaba Diego de Landa, en una forma de la verdad. El exemplum de Nezahualcóyotl, resignificado y expuesto, como si ocupara ahora el lugar de la pieza esencial del museo, es la dovela central que rige la posibilidad misma de existencia y cohesión del archivo.

Figura 5. Il secolo messicano; Caratteri numerali e figure simboliche; L'anno messicano, il mese messicano (Clavigero, 1780-1781, pp. 65, 193 y 71).
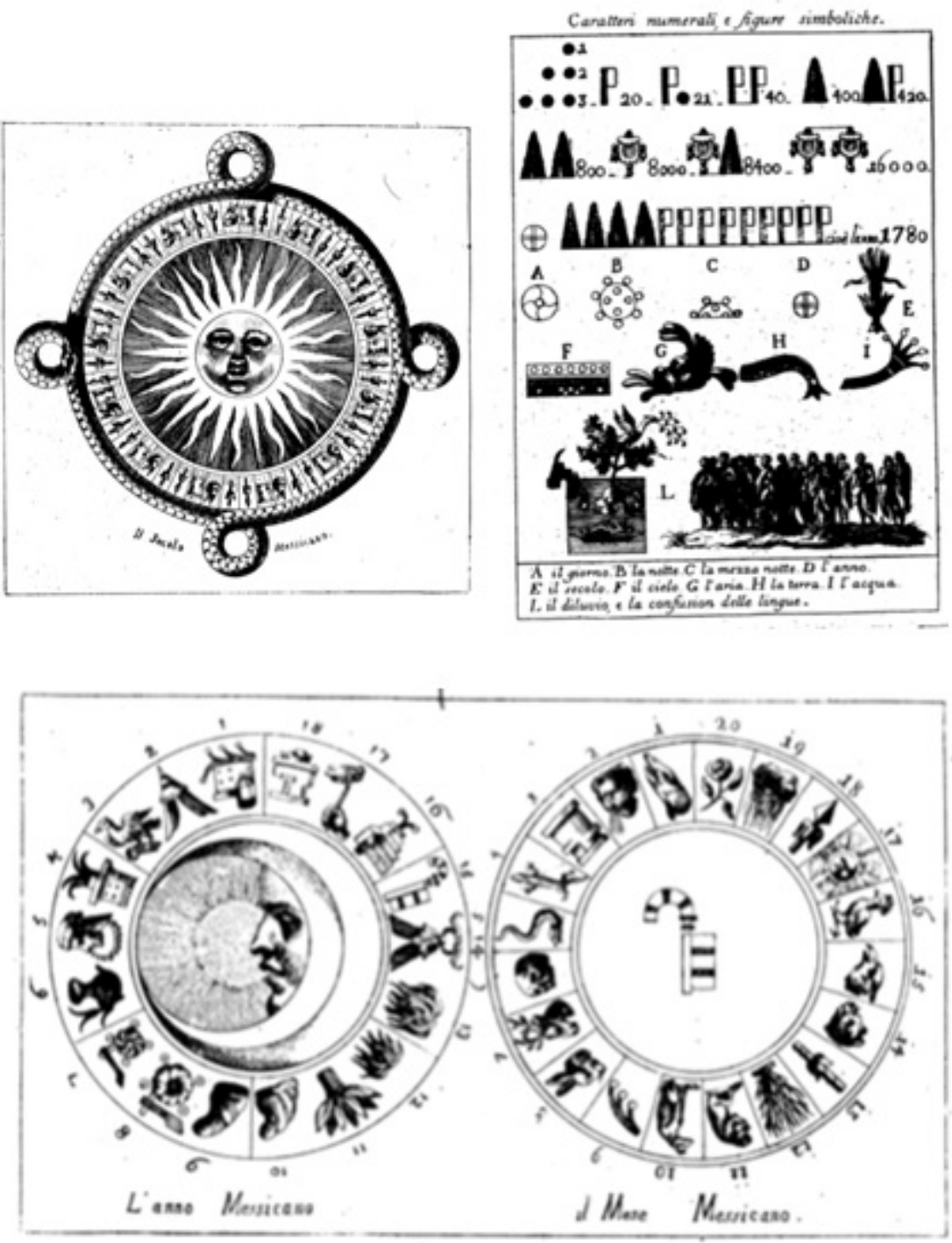

\section{7.}

Este nuevo archivo transculturado que emerge de las paredes imaginarias del museo presupone, en la etapa final del siglo, una remodelación radical de las posiciones enunciativas y de la agencia cultural. La 
"imaginación museística", en suma, como lo afirma Benedict Anderson, siempre es un acto profundamente político (1993, p. 249), que interviene en la realidad redefiniendo y modificando los modos de autorización y transmisión de saberes y determinando también, así, nuevas formas del poder.

Y es claro, además, que las estrategias de conservación del patrimonio cultural que Clavigero bosqueja en su carta-dedicatoria plantean directamente el problema del archivo en tanto cuestión política que introduce una jerarquización de las posiciones culturales en el ámbito de la sociedad novohispana. Para edificar el museo, lo hemos visto, es necesario reivindicar el valor cultural de la historia indígena precortesiana, rescatándola del olvido y de la destrucción a través de la salvaguarda de sus vestigios materiales, para reintegrar, luego, estos últimos al patrimonio de los saberes coloniales. Sin embargo, reintegrar el archivo, conservar sus objetos, supone una acción que en Clavigero coincide con una labor de delimitación de las formas del control sobre el pasado y la tradición. La urgente necesidad de "sacar esta clase de documentos de manos de los indios" (Clavijero, 2009, p. XVIII), que constituye en Clavigero una prioridad en el proceso de formulación del archivo, exhibe esa voluntad para convertir la historia en herramienta a la vez identitaria y política en el contexto de los cambios que, a finales del siglo XVIII, irán remodelando el lugar enunciativo criollo.

No obstante que la conservación del patrimonio sea vista como elemento fundador del archivo, esto no quita que tal conservación esté permeada de ambivalencia, pues opera tanto como dispositivo de asimilación cuanto como principio de exclusión. Por cierto, esta es la naturaleza voraz del museo que subraya Umberto Eco (2014, p. 17), pero es también, y sobre todo, esa interdicción al uso que la imaginación museística impone a los objetos que custodia. Esa separación tajante de la dimensión vital de la cultura es lo que Agamben lee como uno de los dispositivos políticos fundamentales de la modernidad (2005, p. 109). ${ }^{23}$

$\mathrm{Al}$ incluir, el museo tan solo anuncia nuevos modos de separación y de desactivación, procesos complementarios que, en el museo imaginado por Clavigero, redefinen la historia mexicana, articulando las formas y el valor del pasado de acuerdo con las necesidades del presente virreinal. Es significativo, así, que la galería mínima de láminas que en la Historia antigua esboza el proyecto de un museo aún por venir termine bruscamente al finalizar el libro séptimo, es decir, justo en el momento en que el relato historiográfico transitará hacia la descripción de los acontecimientos de la conquista española. Con la llegada del ejército cortesiano se interrumpe, en la visión histórica de Clavigero, la gloriosa historia del México antiguo y se inaugura, en cambio, la etapa de una historia imperial que marcará la esencia misma de la modernidad mexicana. Los antiguos mexicanos, de los que se elogia la cultura y de los que se trata precisamente de rescatar la tradición, nada comparten con la "ínfima plebe" (Clavijero, 2009, p. 300) de los indios que habitan el presente virreinal. La alternancia lexical, transversal a toda la obra clavigeriana, es aquí significativa y revela de manera explícita una nueva forma de la historia que surge como producto de la mirada criolla. El museo inventa el pasado y reconfigura el presente, dotando a la historia de un inédito horizonte de legibilidad que incluye al pasado indígena solo para enfatizar su exclusión de la actualidad virreinal.

El ambiguo proceso de elaboración de este nuevo archivo híbrido que aglutina excluyendo y recupera a lo indígena únicamente para restituirlo bajo la forma de lo inactual, inventa así el tiempo de una tradición mexicana autónoma capaz de sostener las exigencias del espacio enunciativo criollo. Sin embargo, su forma refleja, una vez más, la fisionomía de una tradición, como es la novohispana, esencialmente incongruente y fluida. El museo concretiza de esta manera un dinamismo cultural que, en un ejercicio inacabado de negociaciones, determina la realidad -sus objetos, palabras y prácticas, presentes y pasados- como el campo blanco para la reconfiguración de los sentidos y la imaginación de las identidades.

Hacia 1840, el pintor italiano Pedro Gualdi habrá de entregar la primera imagen del museo esbozado por Clavigero, reproduciendo el aspecto del claustro de la Real y Pontificia Universidad de México en una litografía (figura 6) que se incluirá, al año siguiente, en el volumen antológico Monumentos de Méjico (Gualdi, 1841). En el centro del claustro, a plena luz, la estatua ecuestre de Carlos IV, trasladada al edificio de la universidad en 1824, domina la escena a modo de celebración de la historia imperial mexicana, en un programa expositivo donde la imagen del poder polariza y rige la arquitectura del saber (la Universidad). 
A la izquierda, ocultada por la sombra de los pórticos y detrás de una reja que permite solo el esbozo de su ságoma, la imponente Coatlicue, ya casi excluida del horizonte de la observación de los visitantes, concretiza material y espacialmente el pasado mexica de la nación, otorgando así una forma embrionaria al museo a la vez inclusivo y excluyente imaginado por Clavigero.

Figura 6. Pietro Gualdi, Interior de la Real y Pontificia Universidad de México, hacia 1840.

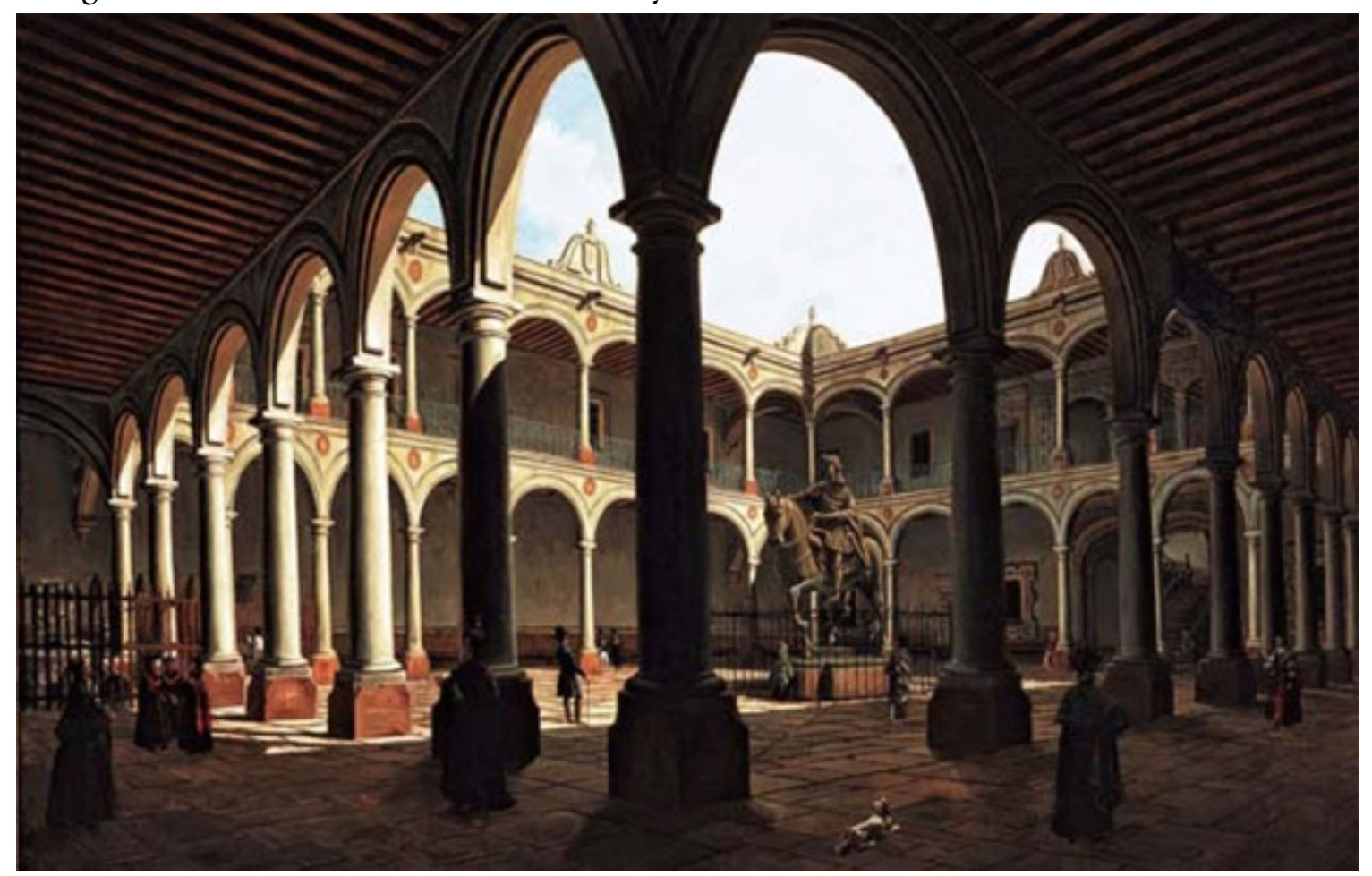

\section{ReFERENCIAS}

Adorno, R. (2014). Carlos de Sigüenza y Góngora (1645-1700): "El amante más fino de nuestra patria”. Hispanófila, $171(1), 11-27$.

Agamben, G. (2005). Profanaciones. Buenos Aires: Adriana Hidalgo.

Alfaro, A., Escamilla, I., Ibarra, A. C. y Reynoso, A. (coords.) (2015). Francisco Xavier Clavigero, un humanista entre dos mundos. Entorno, pensamiento y presencia. México: Fondo de Cultura Económica.

Anderson, B. (1993). Comunidades imaginadas. México: Fondo de Cultura Económica.

Benjamin, W. (2008). Tesis sobre la historia y otros fragmentos. México: UACM.

Brading, D. (1973). Los origenes del nacionalismo mexicano. México: Fondo de Cultura Económica.

Burrus, E. J. (1959). Clavijero and the lost Sigüenza y Góngora manuscripts. Estudios de Cultura Náhuatl, (1), 59-90.

Cabello Carro, M. P. (1989). Coleccionismo americano indígena en la España del siglo XVIII. Madrid: Ediciones de Cultura Hispánica.

Cabello Carro, M. P. (1994). Los inventarios de objetos incas pertenecientes a Carlos V: estudio de la colección, traducción y transcripción de los documentos. Anales del Museo de América, (2), 33-61.

Cabello Carro, M. P. (2001). La formación de las colecciones americanas en España: evolución de los criterios. Anales del Museo de América, (9), 303-318.

Cañizares-Esguerra, J. (2001). How to Write the History of the New World. Histories, Epistemologies, and Identities in the Eighteenth-Century Atlantic World. Stanford: Stanford University Press. 
Clavigero, F. S. (1780-1781). Storia antica del Messico cavata da' migliori storici spagnuolie da' manoscritti, e dallepitture antiche degl'indiani: divisa in diecilibri, e corredata di cartegeografiche e di varie figure: e Dissertazioni Sulla Terra, sugli Animali, e sugli abitatori del Messico, 4 vols. Cesena: Gregorio Biasini.

Clavijero, F. J. (2009). Historia antigua de México. México: Porrúa.

Cuevas, M. (2009). Prólogo. En F. J. Clavijero, Historia antigua de México (pp. IX-XIII). México: Porrúa.

Diderot, D., d'Alembert, J.-B. (1765). Musée. En Encyclopédie, ou dictionnaire raisonné des sciences, des arts et des métiers, vol. 10 (pp. 893-894). Mam-My, Neufchastel: Samuel Faulche\&Compagnie, Libraires\&Imprimeurs.

Díez-Canedo F. A. (2017). Francisco Javier Clavijero, ¿nacionalista, indigenista o ilustrado? Notas para una lectura contextualizada de su Historia antigua de México. Nuevas de Indias. Anuario del CEAC, (2), 30-53.

Eco, U. (2014). El museo en el tercer milenio. En U. Eco e I. Pezzini, El museo (pp. 15-42). Madrid: Casimiro Liberos.

Eco, U. (2016). Vertigine della lista. Milano: Bompiani.

Eguiara y Eguren, J. J. de (1996). Prólogos a la Biblioteca Mexicana. México: Fondo de Cultura Económica.

Florescano, E. (1993). La creación del Museo Nacional de Antropología y sus fines científicos, educativos y políticos. En E. Florescano (comp.), El patrimonio cultural de México (pp. 145-164). México: Consejo Nacional para la Cultura y las Artes-Fondo de Cultura Económica.

Florescano, E. (1999). Memoria indígena. México: Taurus.

Foucault, M. (2001). Des espaces autres. En Dits et écrits, Vol. II, 1976-1988 (pp. 1571-1581). Paris: Gallimard.

Foucault, M. (2002). La arqueología del saber. Buenos Aires: Siglo XXI Editores.

García Canclini, N. (2013). Culturas hibridas: estrategias para entrar y salir de la modernidad. Buenos Aires: Paidós.

Gerbi, A. (1960). La disputa del Nuevo Mundo: Historia de una polémica, 1750-1900. México: Fondo de Cultura Económica.

González Echeverría, R. (2011). Mito y archivo. Una teoría de la narrativa latinoamericana. México: Fondo de Cultura Económica.

Gruzinski, S. (2013). La colonización de lo imaginario. Sociedades indigenas y occidentalización en el México español. Siglos XVI-XVIII. México: Fondo de Cultura Económica.

Gualdi, P. (1841). Monumentos de Méjico: tomados del natural y litografiados por Pedro Gualdi en elaño de 1841. México: Imprenta Litografica de Massé y Decaen.

Hernández, F. (1943). Historia de las plantas de Nueva España. Tomo II, Libros $3^{\circ}$ y $4^{\circ}$. México: UNAM.

Jiménez-Blanco, M. D. (2014). Una historia del museo en nueve conceptos. Madrid: Cátedra.

Lafaye, J. (2002). Abismo de conceptos. En Quetzalcóatl y Guadalupe. La formación de la conciencia nacional (pp. 499-557). México: Fondo de Cultura Económica.

Landa, D. de (1864). Relation des choses de Yucatan de Diego de Landa. Texte espagnol et traduction française en regard comprenant les signes du calendrier et de l'alphabet hiéroglyphique de la langue maya. Paris: Arthus Bertrand Éditeur.

León-Portilla, M. (1996). El destino de la palabra: de la oralidad a los códices mesoamericanos a la escritura alfabética. México: Fondo de Cultura Económica.

López Parada, E. (2018). Botines no venales: traer y llevar sentido. En El botón de seda negra: traducción religiosa y cultura material en las Indias (pp. 353-374). Madrid-Frankfurt am Main: Iberoamericana-Vervuert.

Marchetti, G. (1986). Cultura indígena e integración nacional. México: Universidad Veracruzana.

Martínez Marín, C. (1994). Los códices mexicanos de época colonial. Coleccionismo y éxodo (pp. 10-72). En M. L. Sabau García, M. O. Sáenz González y E. Vargas Lugo de Bosch (eds.). México en el mundo de las colecciones de arte. México: Grupo Azabache.

Montaldo, G. (2001). Teoría crítica, teoría cultural. Caracas: Equinoccio-Ediciones de la Universidad Simón Bolívar.

Morales Moreno, L. G. (1994). Orígenes de la museología mexicana. Fuentespara el estudio histórico del Museo Nacional, 1780-1940. México: Universidad Iberoamericana.

Padgen, A. (1990). Spanish Imperialism and the Political Imagination. New Haven-London: Yale University Press. 
Payàs Puigarnau, G. (2010). El revés del tapiz. Traducción y discurso de identidad en la Nueva España (1521-1821). Madrid-Frankfurt am Main: Iberoamericana-Vervuert.

Paz, O. (1997). Sor Juana Inés de la Cruz, o las trampas de la fe. México: Fondo de Cultura Económica.

Picón-Salas, M. (1944). De la Conquista a la Independencia. México: Fondo de Cultura Económica.

Pomian, K. (2007). Sobre la historia. Madrid: Cátedra.

Reynoso, A. (2018). Francisco Xavier Clavigero. El aliento del Espiritu. México: Fondo de Cultura Económica-Artes de México y del Mundo.

Ronan, C. E. (1970). Clavigero: The Fate of a Manuscript. The Americas, 27(2), 113-136.

Ronan, C.E. (1977). Francisco Javier Clavigero, S.J. (1731-1787): figure of the Mexicanenlightmente: his life and works. Roma-Chicago: Institutum Historicum S. I.-Loyola University Press.

Russo, A. (2011). Cortés's objects and the idea of New Spain: Inventories as spatial narratives. Journal of the History of Collections, 23(2), 229-252.

Sánchez Matías, M. (2014). Francisco Javier Clavijero. Consideraciones en torno a la educación. En N. H. Esquivel Estrada y A. Díaz Ávila (coords.), El entrecruce de la racionalidad en el siglo XVIII novohispano: tradición, modernidad y ética (pp. 173-223). México: Universidad Autónoma del Estado de México-Ediciones Eón.

Sigüenza y Góngora, C. de (1680). Theatro de virtvdes politicas, que constituyen a vn Principe: advertidas en los Monarchas antiguos del Mexicano Imperio, con cuyas efigies se hermoseó el Arco trivmphalque la muy Noble, muyLeal, Imperial Ciudad de Mexico erigio para el digno recivimiento en ella del Excelentissimo Señor Virrey Conde de Paredes, Marques de La Laguna. México: por la Viuda de Bernardo Calderón.

Solodkov, D. M. y Vitulli, J. M. (eds.) (2009). Poéticas de lo criollo: la transformación del concepto "criollo" en las letras hispanoamericanas (siglo XVI al XIX). Buenos Aires: Corregidor.

Ulloa, A. de (1772). Noticias americanas: entretenimientos fisico-históricos sobre la América Meridional, y la Septentrional Oriental: comparación general de los territorios, climas y producciones en las tres especies vegetal, animal y mineral; con una relación particular de los indios de aquellos paises, sus costumbres y usos, de las petrificaciones de cuerpos marinos, y de las antigüedades. Con un discurso sobre el idioma, y conjeturas sobre el modo con que pasaron los primeros pobladores. Madrid: Imprenta Real.

\section{Notas}

1 Lo mismo señala Miguel León-Portilla: "La conquista española y lo que a ella siguió, alteró profundamente la cultura indígena y trastocó de modo particular sus formas de saber tradicional y los medios de preservación de sus conocimientos religiosos, históricos y de otras índoles. Sin exageración puede afirmarse que acarreó la fractura y a la postre la muerte de un sistema de preservación de conocimientos con raíces milenarias” (León-Portilla, 1996, p. 13).

2 Escribimos Clavigero de acuerdo con la grafía del nombre establecida por Ronan (1977) y actualmente aceptada por los estudiosos. Seguimos utilizando la grafía con j en la bibliografía, para las obras que la presentan -como en el caso de la edición canónica en castellano de la Historia antigua de México editada por Mariano Cuevas- y, cuando sea necesario para respetar los textos originales, citados a lo largo de este trabajo.

3 La Historia antigua se publica por primera vez en italiano, en dos volúmenes, entre 1780 y 1781 por la imprenta de Gregorio Biasini en Cesena. Para una historia del manuscrito clavigeriano y de sus diferentes traducciones y ediciones, véase el estudio de Ronan (1970). Para las demás cuestiones relacionadas con el período italiano de Clavigero, sus investigaciones y el contexto histórico y cultural de la redacción de la Historia antigua, véase el estudio biográfico de Ronan (1977).

4 "Sabéis muy bien cuán arduo es el asunto de mi historia y cuán difícil salir de él, principalmente un hombre reducido a un miserable estado por las tribulaciones, que se ha puesto a escribir a más de dos mil y trescientas leguas de su patria, privado de muchos documentos necesarios, y aun de las confrontaciones que pudieran proporcionarle las cartas de sus compatriotas" (Clavijero, 2009, p. XVII).

5 Discuten brevemente de esta lámina y de sus fuentes documentales Díez-Canedo (2017, pp. 38-42) y Cañizares-Esguerra (2001, pp. 238-240).

6 Punto de vista, el criollo, que Clavigero reivindica desde las palabras introductorias de su Historia antigua, delimitando así el lugar enunciativo de su obra: "Una historia de México escrita por un mexicano que no busca protección que lo 
defienda sino conductor que lo guíe y maestro que lo ilumine, debe sin duda consagrarse al cuerpo literario más respetable de este Nuevo Mundo, como el más instruido en la historia mexicana, y más apto para decidir del mérito de tal obra y corregir los defectos que ella tenga" (2009, p. XVII).

7 El proyecto de la Historia antigua de México tiene como su objetivo fundamental el de "restituir a su esplendor la verdad ofuscada por una turba increíble de escritores modernos de la América” (2009, p. XXI) y nace de las contingencias de un debate acerca de América y de los americanos que estalla, en Europa, a partir de algunos escritos del conde de Buffon sobre la naturaleza del Nuevo Mundo y, en particular, con la publicación de las Recherches philosophiques sur les Américains, ou mémoires intéres sants pour servir à l'histoire de l'espèce humaine por Cornelis de Pauw en 1768. Desmentir las visiones de América propuestas por los ilustrados europeos es la función primaria que tienen las nueve Disertaciones que Clavigero adjunta al segundo volumen de la primera edición italiana de la Storia antica en 1781 y que abocan abiertamente a deslegitimar "el monstruoso retrato que Paw hace de la América" (2009, 598). Sobre la historia de esta disputa que polariza durante el siglo XVIII gran parte de los intelectuales europeos y americanos remitimos a la monumental investigación de Gerbi (1960).

8 Sobre este asunto véase también el trabajo de Picón-Salas (1944, pp. 145-162).

9 En la dedicatoria del Teatro, dirigida al Virrey Conde de Paredes, Sigüenza y Góngora inscribe su proyecto del arco triunfal en el ámbito de una acción de rescate del pasado indígena, que evoca, significativamente, perdido en el olvido: "Y òi era destino de la Fortuna, el q\#en alguna ocaòion renacieòen los Mexicanos Monarchas de entre las cenizas en que los tiene el olvido, para que como Fenizes del Occidente los inmortalizaòe la Fama: nunca mejor pudieron obtenerlo, que en la preòente, por haver de òer V. Ex.a quien les infudieòe el espiritu, como otras vezes lo à hecho òu Real, y excelentiòòima Caòa, con las que iluòtran la Europa" (1680, p. V). Para esta y otras cuestiones que en Sigüenza y Góngora determinan un proceso de rescate del pasado indígena de México, remitimos al estudio de Rolena Adorno (2014, p. 13).

10 David Brading (1973) reconstruye este proceso que anima la cultura novohispana del siglo XVIII y que llevará, luego, a la independencia nacional en el XIX.

11 Presentando las finalidades de su historia, Clavigero sostiene que su obra es el fruto del trabajo "de un ciudadano que (...) se ha empleado en esto para ser útil a su patria" (2009, p. XXVII). Marchetti, por otro lado, especifica los significados que Clavigero atribuye a los dos términos de patria y nación: "En el curso de su obra, Clavijero emplea el término 'nación' para indicar una unidad cultural y política: se inspira, en fin, en el sentido clásico de la palabra y, al mismo tiempo, en el que ésta tiene en la Escritura, donde está por 'pueblo', conjunto étnico del cual la lengua constituye el principal factor unificante. Es importante subrayar el valor decisivo que para Clavijero desempeñan los caracteres culturales: para él 'nación' no se identifica necesariamente con 'raza'. Meticulosa es la distinción que él mantiene, siempre, entre 'patria' y 'nación' [...]. Los indios mexicanos son «compatriotas», esto es nacidos en el mismo lugar que él; los 'nacionales' (...) son los españoles: la 'nación’ es España” (1986, pp. 133-134).

12 Son estas, en fin, las preguntas esenciales que para Cañizares-Esguerra (2001) determinan una serie de cambios fundamentales en las relaciones atlánticas durante el siglo XVIII y que, como acontece también en el caso de la Historia antigua de México de Clavigero, empujarán las culturas criollas virreinales americanas hacia una redefinición radical de los parámetros que habían regido hasta entonces las relaciones entre pasado indígena y presente colonial.

13 Martínez Marín (1994, p. 13) esboza rápidamente los capítulos fundamentales del coleccionismo de objetos indígenas en el ámbito del Virreinato de la Nueva España, desde el siglo XVI hasta el XVIII. Otra interesante reconstrucción de la colección de Carlos de Sigüenza y Góngora, a partir de los documentos dejados por Alva Ixtlilxóchitl y hasta su difusión en los historiadores dieciochescos, es la elaborada por Ernest J. Burrus (1959).

14 López Parada (2018) analiza las implicaciones que tiene este proceso de incorporación de la materialidad indiana en el sistema cultural europeo. Para una reflexión sobre las primeras colecciones de objetos americanos en el siglo XVI y su función en la construcción discursiva e imaginaria de lo americano en el contexto del pensamiento europeo, se remite al trabajo de Russo (2011) sobre la colección de objetos que Hernán Cortés recogió en el curso de su campaña militar y que envío a Carlos V. Por lo que atañe a las primeras colecciones provenientes de Perú, véase Cabello Carro (1994). Una visión de conjunto sobre la musealización de objetos indígenas en la España del siglo XVIII es la que ofrece el estudio de Cabello Carro (1989).

15 En este sentido, resultan paradigmáticas las palabras que escribe Antonio de Ulloa en sus Noticias americanas, texto que acota conceptualmente la reapertura del segundo Gabinete de Historia Natural en Madrid en 1771, principal centro expositivo de la materialidad americana en la capital imperial: "las memorias de la antigüedad son las demostraciones verídicas de lo que fueron las gentes en los tiempos a que se refieren: por ellas viene a averiguarse lo que alcanzaron, el modo en que se manejaron, su gobierno y economía; y a este respecto lo que han adelantado o perdido, lo numeroso de sus gentíos, la industria, el valor, y las máximas de manejarse; sin los documentos, que sin embargo de la ruina de los tiempos, se conservan en alguna parte, no habría documentos formales de donde inferirlo. De ellos se comprende la semejanza que tuvieron unos pueblos por otros; y por este medio se llega, en aquella forma que es posible, a desentrañarse su origen, que es una de la particularidades que más incitan al deseo, como sucede con los indios, que por estar separados de las otras tierras, y por tener disonancia en el color, y en otros accidentes de la contextura, dificulta el juicio el modo de haber 
transitado a poblar, y el origen de donde salieron. Estos asuntos serían de la mayor confusión para el entendimiento, si no se les encontrase una solución regular en los vestigios de las cosas, en los usos, las costumbres, y las demás particularidades que descubre la investigación, ayudada de la inteligencia” (Ulloa, 1772, s/p).

16 Reproducimos las láminas de la primera edición italiana de la Storia antica del Messico (Clavigero, 1780-1781).

17 Sobre el enciclopedismo que modela el nacimiento del museo moderno remitimos al trabajo de Jiménez-Blanco (2014, pp. 78-79). En la Encyclopedie, por otro lado, Diderot y D’Alambert destacan precisamente la función científica y educativa del museo, describiendo rápidamente el Museo Ashmolean, abierto en 1683 en la Universidad de Oxford y que constituyó posiblemente uno de los modelos del museo imaginado de Clavigero: "Le muòée d'Oxford, appellémuòéeashmoléen, eòt un grandbâtimentque l'Univeròité a fait conòtruire pour le progrès\& la perfectiondesdifférentesòciences. Il futcommencé en 1679 \&achevé en 1683. Dans le mêmetems, ÉlieAshmole, écuyer, fitpréòent à l'univeròité d'Oxford d'une collection conòidérable de curioòités qui y furentacceptées, \& enòuitearrangées\& miòes en ordre par le docteurPlott, qui futétabli premier gardedumuòée" (Diderot-D’Alembert, 1765, p. 894).

18 Sánchez Matías (2014) discute más en detalle este elemento esencial de la actividad intelectual clavigeriana, comparando las diferentes vertientes de la obra del jesuita -a saber, la de las ciencias naturales, sobre todo a través de su Physica Particularis, de la historiografía y de la teología - desde la perspectiva de la elaboración de una filosofía de la educación. Para un análisis de la filosofía clavigeriana remitimos al excelente trabajo de Reynoso (2018) y al volumen colectivo recopilado por Alfaro, Escamilla, Ibarra y Reynoso (2015).

19 La descripción de esta flor y su imagen están sacadas directamente del texto de Hernández. Clavigero, sin embargo, reduce al mínimo el aparato textual que ofrece el botánico, hasta retener exclusivamente los caracteres superficiales de la taxonomía científica. Hernández, por otro lado, elude casi por completo de la función cultural que esta flor desempeñaba en el contexto social mexica (Hernández, 1943, pp. 378-380).

20 Clavigero volverá sobre este asunto en su octava Disertación (Clavijero, 2009, pp. 811-821), reconstruyendo en breve una historia del sacrificio humano que va desde la clasicidad romana, griega y egipcia, hasta las Escrituras, para llegar al final a la religión de los antiguos españoles y destacando, por último, que "la frecuencia de tales sacrificios no fue menor en Egipto, Italia, España y las Galias que en México" (2009, p. 819).

21 Anthony Padgen describe del siguiente modo el proceso de revisión histórica que anima las páginas clavigerianas, reconduciéndolo a las necesidades culturales e identitarias de la clase criolla mexicanas de finales del siglo XVIII: "What Clavigero set out to do was to reappropriate for the criollo élite what he referred to as 'the remains of the antiquities of our patria' and out of that to create a classical antiquity which would serve the 'Mexicans' as the past of Greece and Rome had served the Europeans, as a culture to be shared with the ancient Mexicans with whom they were connected by place, not race" (1990, p. 101).

22 Sobre esta genealogía que encuentra en el museo imaginado clavigeriano los antecedentes teóricos fundamentales para la museología mexicana de los siglos XIX y XX, remitimos a la investigación de Morales Moreno (1994).

23 En esta misma perspectiva, Morales Moreno lee el proyecto museal clavigeriano en los términos de una "operación dual de despojo-reapropiación del pasado" (1994, p. 32). 